\section{Hail damage to a new white spruce and lodgepole pine plantation in central British Columbia}

\author{
R. C. DOBBS and R. G. MCMINN
}

Department of the Environment

Conadian Forestry Service.

Pacific Forest Research Centre

Victoria, British Columbia
Les dommages de la grële sur une plantation dépinette blanche et de pin de Murray en Colombie Britannique centrale. Une violente tempête de grêle qui dura 10 minutes entraina des dommages (défoliation, blessures à la tige, branches et flèches terminales cassées) atteignant jusqu'à $86 \%$ des arbres âgés de 2 à 4 ans dans la plantation. Les dommages furent plus importants sur le pin de Murray que sur l'épinette blanche. De plus, les arbres plus âgés et plus grands subirent plus de dégâts que les arbres plus jeunes et plus petits. La végétation environnante fournit une certaine protection contre la défoliation.
Hail, bane of the agriculturist and insurance adjuster, is rarely noted as a cause of damage to forest trees. Yet, when severe hailstorms occur, damage to forest vegetation may be both dramatic and serious. We report here on the immediate effects of one hailstorm on recently planted white spruce (Picea glauca (Moench) Voss) and lodgepole pine (Pinus contorta Dougl. var. latifolia Engelm.) trees near the village of Upper Fraser in central British Columbia.

\section{Observations}

A drop in temperature from $65^{\circ} \mathrm{F}$ to $45^{\circ} \mathrm{F}$ immediately preceded the storm which occurred at 1630 on 23 July, 1972. Hailstones from one to one-and-a-half inches in diameter, driven by strong southwest winds, pelted down continuously for about 10 minutes causing substantial damage to aluminum roofs and other property in Upper Fraser. The swath of the storm was over 5 miles wide; its length was undetermined.

The opportunity to make the observations and comparisons reported here resulted from the "mixed blessing" of having Canadian Forestry Service regeneration research plots directly in the path of the storm. The plots contained planted spruce and pine trees of three ages: 4-year-old transplants (2-1 stock planted in fall, 1970), 3-year-old seedlings (2-0 stock planted in spring, 1971) and 2year-old seedlings (2-0 stock planted in spring, 1972). The plots had received various site preparation treatments and covered a range of site types. In some plots, the seedlings had been stratified into three size classes at the time of planting small, medium and large.

The plots were inspected immediately after the storm, and in mid-September the degree of defoliation, presence of stem lesions and death of terminal buds or leaders were assessed. Defoliation was assessed as heavy if the loss was greater than $50 \%$ for pine or $30 \%$ for spruce. (The different criteria were adopted because of greater defoliation on pine. The effect is to exaggerate the defoliation of spruce compared to pine and to under-emphasize the difference between them. In retrospect, $50 \%$ should have been adopted as the criterion for both species.) Lesions were recorded only if they were on the main stem and were greater than $3-\mathrm{cm}$ long. Over 1500 trees of each species were assessed.

Ground vegetation was flattened by the storm and within a week, dead and wilted leaves resembled the effects of autumn frosts. However, within a month, the shrubs had made a vigorous recovery. Defoliation, stem lesions and broken branches and leaders were evident on most smaller trees and the litter of twigs covering roads adjacent to mature standing timber showed that large trees had not escaped damage. Damage to leaders in a 5 -year-old spruce plantation was similar to that resulting from a serious outbreak of spruce weevil.

Of 3122 trees examined, $14 \%$ were undamaged and $2 \%$ were killed by hail; the rest suffered varying degrees of damage. Typical damage was defoliation, stem lesions which were confined to the windward side of stems, and dead leaders usually caused by extensive wounding of the bark (Figs. 1 and 2).

Damage to lodgepole pine was generally greater than that to white spruce (Fig. 3). Heavy defoliation was observed on $49 \%$ of the planted pine, compared to $28 \%$ on spruce; $62 \%$ of pine suffered stem lesions, compared to $57 \%$ for spruce; dead leaders or terminal buds were noted on $51 \%$ of the pine and on only $39 \%$ of the spruce.

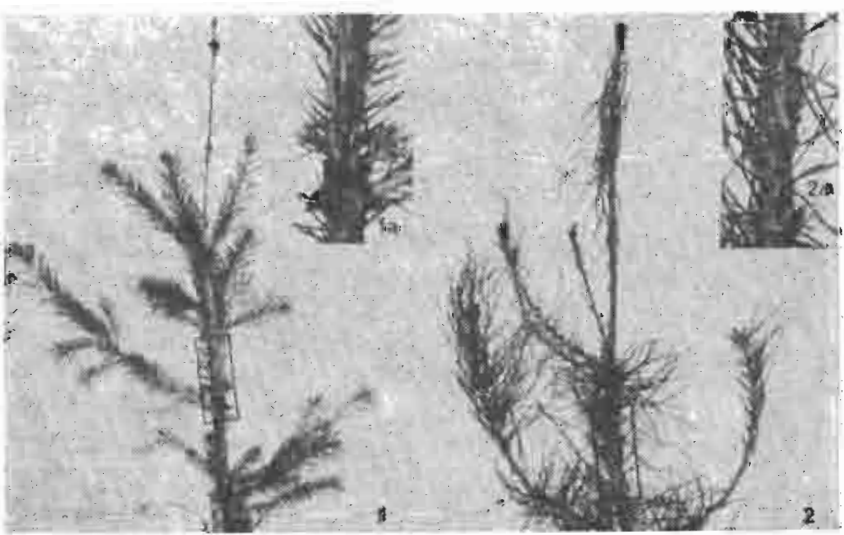

Fig. 1. Four-year-old white spruce transplant partially defoliated by hail. Inset: Hoil lesion on stem of same transplant.

Fig. 2. Four-year-old lodgepole pine transplant partially ciefo. liated by hail. Inset: Hail lesion on stem of same transplant. 
DEAO LEADER OR GUD STEM LESIONS -

HEAVY DEFOLIATION-

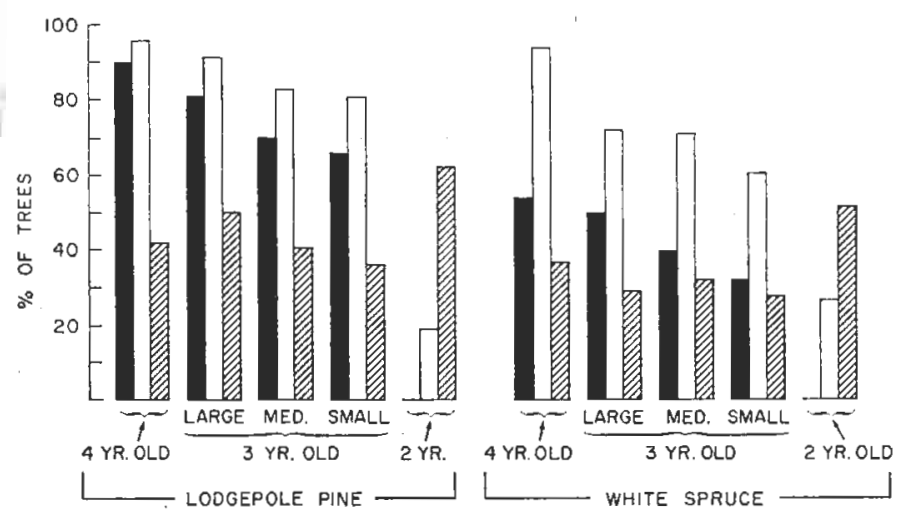

Fig. 3. Per cent of trees damaged by type of injury and species and stature of tree.

Older and larger trees generally suffered greater damage by defoliation and stem wounding than younger and smaller ones (Fig. 3). For example, heavy defoliation of pine was evident on $90 \%$ of the 4-year-old transplants, decreasing to $81 \%, 70 \%$ and $66 \%$, respectively, on the large, medium and small 3-year-old seedlings, and was absent on the 2-year-old seedlings. A similar relationship was revealed by spruce. Stem lesions decreased with decreasing age and size of trees for both species. The distribution of leaders and terminal buds killed by hail was not as regular.

Surrounding vegetation seemed to have some effect in reducing defoliation and wounding of planted trees. Sixty-four per cent of those growing on scarified sites which were relatively free of vegetation were heavily defoliated, compared to $57 \%$ amid the dense vegetation of untreated sites. Similarly, stem lesions were observed on $80 \%$ of the trees on scarified sites, compared to $70 \%$ on untreated sites. Vegetation provided no protection against injury to leaders and terminal buds.

\section{Discussion}

The adage "the bigger they are, the harder they fall" seems to apply to damage of young trees by hail. A greater proportion of the larger transplants and seedlings sustained apparent damage in part because they offer a larger target. However, the greater suppleness of the smaller and younger trees may also help them avoid severe defoliation and stem wounding. This suggestion is supported by the much lower incidence of defoliation and wounding on the 2-year-old seedlings for both species than on the small 3-year-old seedlings which were of similar height. The greater leader and terminal bud damage on the 2-year-old seedlings is probably due to their having been planted only weeks before the storm and, consequently, having a very succulent leader still in an active stage of growth.

Defoliation of spruce trees generally resulted from twigs being broken or entire needles being stripped from twigs. Broken twigs were less frequent in pine, and defoliation commonly took the form of broken needles with a stub remaining attached to the twig (Fig. 1B). A similar result could be obtained by snapping a needle with one's finger. The larger target afforded by the longer, more brittle pine needles was undoubtably a factor in their greater susceptibility to defoliation. The greater incidence of stem wounding suffered by pines was probably due to their having thinner, more tender bark than the spruce. Riley (1953) reported more severe stem wounding by hail in the tops of jack pine trees than in white spruce trees.

The real impact of the storm on young plantations can only be surmised. However, the extensive initial damage may lead to some subsequent mortality or growth reduction. Pechmann (1958), reporting on hail damage in the Alps, noted that spruce seedlings died if defoliation exceeded $60-70 \%$, and Davies (1961) judged that Scots pine seedlings which had most of their current year's growth stripped off by hail were so damaged that they were unlikely to produce stems of timber quality. The New Zealand Forest Service reported that hail damage to stems and foliage of young planted Pinus radiata was still in evidence after 3 years and that growth had been retarded (Anonymous 1947). Linzon (1962), reporting on hail damage to 5-7 inch dbh white pine trees, also blamed hail for losses in height and diameter growth.

Hail damage has been implicated by several authors as a predisposing factor in insect and fungal attacks (e.g. Benjamin 1957, Gilmour 1960, Hawksworth and Hinds 1960). However, Linzon (1962) and Ouellette (1967) determined that important heartrot fungi seldom became established in fresh hail wounds.

In summary, it appears that forest plantations in the path of severe hailstorms are liable to heavy damage. Results may include direct mortality and degrade, reduction of growth and secondary losses to insects and fungi. Plantations known to have been hit by hailstorms should be surveyed to determine the extent of damage and possible requirement for replanting.

\section{References}

ANONYMOUS. 1947. Hail damage. Rep. N.Z. Forest Serv, 1946-47. p. 24.

BENJAMIN, D. M. 1957. Hail damage to five-year-old red pine in northern Wisconsin. Forest Sci. 3: 249-252.

DAVIES, W. J. 1961. Abnormal growth of Scots pine following hailstorm damage. Quart. J. Forest. 55: 164-167.

GILMOUR, J. W. 1960. The importance of climatic factors in forest mycology. New Zeal. J. Forest. 8: 250-260.

HAWKSWORTH, F. G. and T. E. HINDS. 1960. Cytospora canker of Engelmann spruce in Colorado. Plant Disease Rep. 44: 72.

LINZON, S. N. 1962. Hail damage to white pine and other trees. Forest. Chron. 38: 497-504.

OUELLETTE, G. B. 1967. Microflora of hail wounds. Can. Dep. Forest. Rural Devel. Bi-Mon. Res. Notes 23: 46.

PECHMANN, $\mathrm{H}$. von. 1958. (The prospects for recovery in forest stands damaged by hail.) Forstwiss. Cabl. 77: 357 373. (Original not seen; cited from Forest. Abstr. 20: 3282).

RILEY, C. G. 1953. Hail damage in forest stands, Forest. Chron. 29: 139-143. 